\title{
Distribution related to temperature and salinity of the shrimps Acetes americanus and Peisos petrunkevitchi (Crustacea: Sergestoidea) in the south-eastern Brazilian littoral zone
}

\author{
SABRINA MORILHAS SIMÕES ${ }^{1,2}$, ANTONIO LEÃO CASTILHO ${ }^{2}$, ADILSON FRANSOZO ${ }^{2}$, \\ MARIA LÚCIA NEGREIROS-FRANSOZO ${ }^{2}$ AND ROGERIO CAETANO DA COSTA ${ }^{1}$ \\ ${ }^{1}$ LABCAM (Laboratório de Biologia de Camarões Marinhos e de Água Doce), Departamento de Ciências Biológicas, Faculdade de \\ Ciências, UNESP, 17033-360, Bauru, SP, Brasil, ${ }^{2}$ Departamento de Zoologia, Instituto de Biociências, UNESP, 18618-ooo, Botucatu, \\ SP, Brasil
}

\begin{abstract}
The abundance and ecological distribution of Acetes americanus and Peisos petrunkevitchi were investigated from July 2006 to June 2007, in Ubatuba, Brazil. Eight transects were identified and sampled monthly: six of these transects were located in Ubatuba bay, with depths reaching $21 \mathrm{~m}$, and the other two transects were in estuarine environments. A total of 33,888 A. americanus shrimp were captured, with the majority coming from the shallower transects (up to $10 \mathrm{~m}$ ). Conversely, 6,173 of the P. petrunkevitchi shrimps were captured in deeper areas (from 9 to $21 \mathrm{~m}$ ). No individuals from either species were found in the estuary. The highest abundances obtained for both species were sampled during the summer. Canonical correlation analysis resulted in a coefficient value of $0.68(\mathrm{P}=0.00)$. The abundance of both species was strongly correlated with depth. Variations in temperature and salinity values were also informative in predicting the seasonal presence of $\mathrm{P}$. petrunkevitchi in deeper areas and $\mathrm{A}$. americanus in the shallower areas of the bay. It is conceivable that the shrimp adjust their ecological distribution according to their intrinsic physiological limitations.
\end{abstract}

Keywords: abundance, spatio-temporal distribution, pelagic shrimp

Submitted 8 May 2012; accepted 27 May 2012; first published online 9 August 2012

\section{INTRDDUCTION}

The shrimp Acetes americanus Ortmann, 1893 is distributed throughout the western Atlantic from the Guayanes Beach in Porto Rico (northern limit) to Rio Grande do Sul, Brazil (southern limit), while Peisos petrunkevitchi Burkenroad, 1945 is distributed from Rio de Janeiro to Rio Grande do Sul in Brazil to the Chubut Province in Argentina (D'Incao \& Martins, 2000).

Located along the northern coastline of the State of São Paulo, the Ubatuba region is an important area for crustacean research because of its high species richness. For example, from all of the Dendrobranchiata species recorded in Brazilian waters, $33 \%$ were found in this region (Costa et al., 2000, 2003). Four rivers flow into the bay: Acaraú River, da Lagoa River, Grande de Ubatuba River and Indaiá River. As Ubatuba city is an important tourist destination, its influence on water quality in the bay is significant (CETESB, 1996, 2000; Abessa \& Burone, 2003). According to Burone \& Pires-Vanin (2006), large amounts of untreated sewage from the city are

Corresponding author:

R.C. Costa

Email: rccosta@fc.unesp.br discharged into the bay predominantly during the peak summer vacation season (rainy periods).

On the shelf of Ubatuba, South Atlantic Central Water (SACW: $\mathrm{T}<20^{\circ} \mathrm{C}$ and $\mathrm{S}<36$ ) enters the region during the summer and spring months, and a strong thermocline is established during the period (Campos et al., 1995; Castro-Filho \& Miranda, 1998). The opposite occurs during the winter months, when the Tropical Water mass (TW: $\mathrm{T}>20^{\circ} \mathrm{C}$ and $\left.\mathrm{S}>36\right)$ maintains the region under oligotrophic conditions (Valentin \& Monteiro-Ribas, 1993).

Environmental factors, such as the texture of sediment, salinity and temperature, are fundamentally important in determining the spatio-temporal distribution of shrimp (Dall et al., 1990). Sergestidae shrimps play an important role in the marine food chain, as they feed on a variety of food items, such as diatoms and copepods; they are preyed upon by the jellyfish Chiropsalmus quadrumanus (Müller, 1859), by crustaceans, such as the shrimp Pleoticus muelleri (Bate, 1888), as well as sciaenid fish (Xiao \& Greenwood, 1993; Nogueira Júnior \& Haddad, 2008; Roux et al., 2009).

Penaeid shimps are benthic and will bury themselves in the sediment (Castilho et al., 2008a; Simões et al., 2010). Alternatively, Omori (1974) found that the Sergestidae genera of Sergestes, Acetes (H. Milne-Edwards, 1830), Lucifer (Thompson, 1829) and some species of Sergia spp. are epipelagic and mesopelagic, transparent or semi-transparent, and 
generally occur near the materials associated with ocean floor substrates.

Changes in temperature, salinity, tides, wind, food availability and predator presence can all be responsible for fluctuations in sergestid shrimp catches (Xiao \& Greenwood, 1993). Moreover, vertical migration of these shrimps in the water column also occurs, although Williams (1965) and Xiao \& Greenwood (1993) found the greatest abundances of $A$. americanus (Ortmann, 1893) and Acetes chinensis (Hansen 1919), respectively, near the substrates.

Thus far, few studies have been carried out concerning the life history of pelagic shrimps found off the coast of Brazil, with the majority of studies focused predominantly on biodiversity, systematics and larval development (Calazans, 1994; Oshiro \& Omori, 1996; Costa et al., 2000; D’Incao \& Martins, 2000; Calazans, 2002).

Due to the lack of studies concerning the biology of this group, and because they are an important food resource for many species, the present study was conducted to investigate the spatio-temporal distribution of $A$. americanus and $P$. petrunkevitchi across a depth gradient off the coast of Ubatuba, the northern coast of the State of São Paulo, Brazil. Furthermore, we evaluated the influences of temperature and salinity variation on the abundance of these species.

\section{MATERIALS AND METHODS}

\section{Sampling}

Six collection points with differing depths ( $\mathrm{P}_{1}: 1 \mathrm{~m}, \mathrm{P}_{2}: 5 \mathrm{~m}$, $\mathrm{P}_{3}$ : $9 \mathrm{~m}, \mathrm{P}_{4}: 13 \mathrm{~m}, \mathrm{P}_{5}: 17 \mathrm{~m}$ and $\mathrm{P}_{6}: 21 \mathrm{~m}$ ) in Ubatuba bay and two (P7: $1 \mathrm{~m}$ and P8: $1 \mathrm{~m}$ ) in an estuary that flows into the bay were identified, with sampling conducted during the day at high tide. The points were sampled on a monthly basis from July 2006 to June 2007 (Figure 1).

Surface and bottom water temperatures and salinity were monitored monthly at each transect using a Van Dorn bottle for water sampling. Water temperatures $\left({ }^{\circ} \mathrm{C}\right)$ at the bottom were taken using a reversing thermometer attached to the Van Dorn bottle and a standard thermometer at the surface, both with a precision of $0.1^{\circ} \mathrm{C}$. Salinity values were obtained using a refractometer on water samples taken at the bottom and at the surface.

The samples were collected using an aluminium fishing boat with a $25 \mathrm{HP}$ stern drive engine. The shrimp were captured with an otter trawl with a 2-m opening between doors, 3-m mesh length and a height of approximately $1 \mathrm{~m}$ (mesh size was $5 \mathrm{~mm}$ and $0.5 \mathrm{~mm}$ in the cod end). A cup was attached to the extreme end of the net to allow storage of the captured organisms. Each trawl was $50 \mathrm{~m}$ in length, and the effort in each transect was $100 \mathrm{~m}^{2}$.

In the laboratory, all the shrimps were identified according to D'Incao \& Martins (2000) and Costa et al. (2003) and quantified by transect and month in which they were sampled.

\section{Data analysis}

The sampling points in the bay were arranged into 2 groups, one with depths from 1 to $9 \mathrm{~m}$ corresponding to $\mathrm{P}_{1}, \mathrm{P}_{2}$ and $\mathrm{P}_{3}$ (Zone 1) and the other with depths from 13 to $21 \mathrm{~m}$ corresponding to $\mathrm{P}_{4}, \mathrm{P}_{5}$ and $\mathrm{P} 6$ (Zone 2). The shallow region (Zone 1 ) of the bay is strongly affected by coastal environmental conditions, receiving freshwater drainage from four rivers (Acaraú River, da Lagoa River, Grande de Ubatuba River and Indaiá River), while the deep stratum (Zone 2) is subject to greater oceanic influence.

Tests for homoscedasticity (Levene tests) and normality (Shapiro-Wilk tests) were first performed as prerequisites for the statistical test, and the data were then log-transformed prior to analyses (Zar, 1999). Data sets were normally distributed with homogeneous variances.

Abundance (total number of shrimps) was compared among periods (Seasons) and depths (Zones) using analysis of variance (ANOVA Factorial, $P<0.05$ ). The relationship between the environmental factors and the observed abundance patterns in the sergestid species was assessed using canonical correlation analysis (CCorrA). This analysis is a multivariate statistical procedure that directly measures the strength of the relationship between the two sets of variables. The first set used for the CCorrA included the environmental

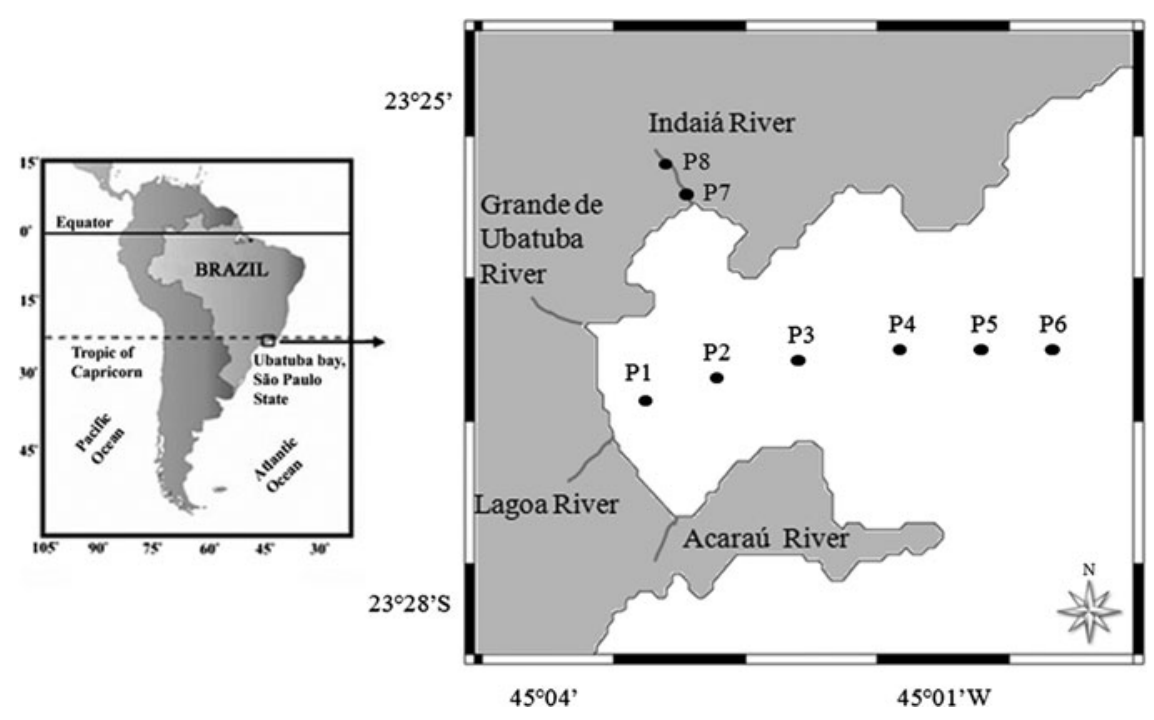

Fig. 1. Map of the Ubatuba region indicating the locations for the collecting points. 
characteristics (salinity, temperature and depth), whereas the second set of variables included the abundance of the studied species (A. americanus and P. petrunkevitchi).

\section{RESULTS}

\section{Environmental factors}

Water surface temperatures did not vary greatly among transects, although the average bottom water temperature was higher in Zone 1 ( 23.25 to $\left.26.29^{\circ} \mathrm{C}\right)$ compared with Zone 2 $\left(21.95\right.$ to $\left.23.16^{\circ} \mathrm{C}\right)$. In the estuary, there was no variation in temperatures between transects (Table 1 ).

Higher variations between bottom and surface temperatures were observed from December 2006 to January 2007 (end of spring and beginning of summer), which contrasted with the autumn and winter months, when homogeneity was the norm (Figure 2).

The average values of salinity in the surface were lower in Zone 1 (29.16 to 33.04) than in Zone 2 (34.33 to 35.08). The values of bottom salinity also showed the same pattern, from 29.75 to 34.25 in Zone 1 and from 34.41 to 35.58 in Zone 2. In the estuary, the average salinity of P8 was lower than that of $\mathrm{P}_{7}$ (Table 1). Higher variations in the salinity values between surface and bottom waters were also found for the December 2006 and January 2007 sampling periods (Figure 3).

\section{Ecological distribution}

No individuals from the targeted species were captured in the Indaiá estuary from July 2006 to June 2007 . However, a total of 33,888 A. americanus specimens were captured in the bay, into which the Indaiá River flows. Shrimp abundance decreased as the depth increased from 1 to $21 \mathrm{~m}$. The $P$. petrunkevitchi catch was 6,173 individuals, with none found in the shallow transects at depths of 1 and $5 \mathrm{~m}$; however, they were caught at deeper locations (Figure 4).

The highest abundances of $A$. americanus were found in November and December of 2006 and April and May of 2007, corresponding to the spring and autumn seasons. The highest abundances of $P$. petrunkevitchi were registered in November of 2006 and January, February, April, May and June of 2007 with no individuals captured in the other months (Figure 5). The abundances differed statistically between zones (ANOVA, $P<0.05$ ) (Table 2).

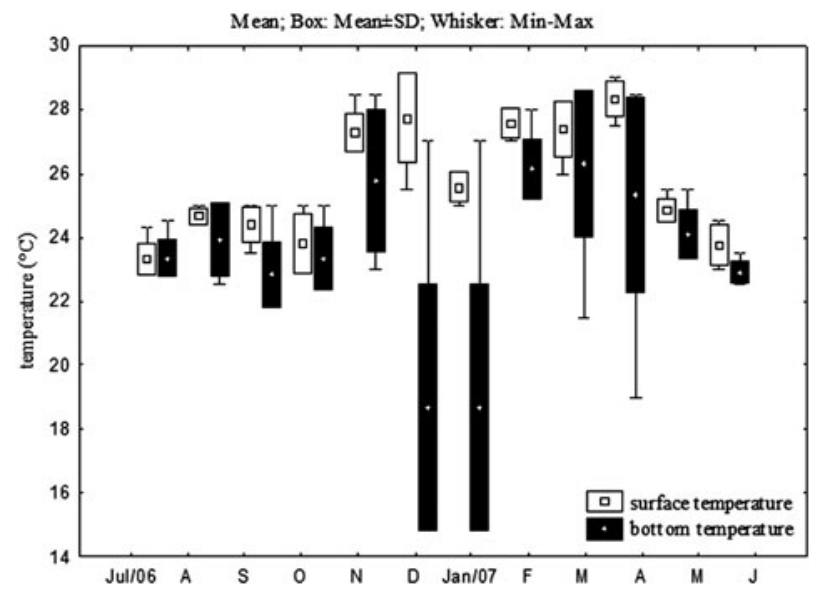

Fig. 2. Monthly mean values and standard deviations (SD) from July 2006 to June 2007 for bottom and surface water temperatures $\left({ }^{\circ} \mathrm{C}\right)$ with maximum and minimum values in the Ubatuba bay, São Paulo.

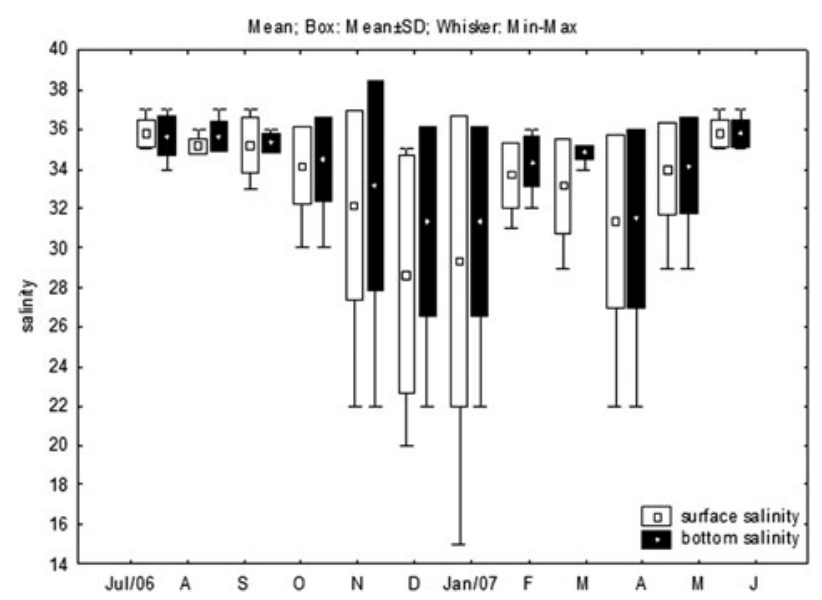

Fig. 3. Monthly mean values and standard deviations (SD) from July 2006 to June 2007 for salinity measures of bottom and surface water with maximum and minimum values in the Ubatuba bay, São Paulo.

The CCorrA resulted in a canonical correlation coefficient of $0.68(P=0.0000001)$. The first root was statistically significant $(P=0.02)$; with the canonical factor loadings (the correlation between the canonical and the original variables) and the canonical weights (the partial correlations of the original variables with respect to the canonical root) shown in Table 3. The environmental variable with the highest factor

Table 1. Average values of temperature $\left({ }^{\circ} \mathrm{C}\right)$, salinity and associated standard deviations (SD) for samples in the Ubatuba bay and in the estuary from July 2006 to June 2007.

\begin{tabular}{|c|c|c|c|c|c|c|}
\hline & & & \multicolumn{2}{|c|}{ Temperature \pm SD } & \multicolumn{2}{|l|}{ Salinity \pm SD } \\
\hline & & & Surface & Bottom & Surface & Bottom \\
\hline \multirow[t]{6}{*}{ Bay } & Zone 1 & $\mathrm{P}_{1}$ & $26.19 \pm 1.61$ & $26.29 \pm 1.61$ & $29.16 \pm 7.02$ & $29.75 \pm 6.01$ \\
\hline & & $\mathrm{P}_{2}$ & $25.74 \pm 1.60$ & $23.33 \pm 2.94$ & $33.04 \pm 2.73$ & $34.08 \pm 1.67$ \\
\hline & & $\mathrm{P}_{3}$ & $25.28 \pm 1.46$ & $23.25 \pm 2.98$ & $32.70 \pm 4.56$ & $34.25 \pm 2.30$ \\
\hline & Zone 2 & $\mathrm{P}_{4}$ & $25.87 \pm 2.17$ & $23.16 \pm 3.26$ & $34.33 \pm 1.56$ & $34.75 \pm 0.43$ \\
\hline & & $\mathrm{P}_{5}$ & $25.60 \pm 2.10$ & $22.66 \pm 3.20$ & $34.91 \pm 0.64$ & $35.41 \pm 0.76$ \\
\hline & & P6 & $25.60 \pm 2.16$ & $21.95 \pm 3.23$ & $35.08 \pm 0.96$ & $35.58 \pm 0.76$ \\
\hline \multirow[t]{2}{*}{ Estuary } & & $\mathrm{P}_{7}$ & $25.00 \pm 2.61$ & $25.00 \pm 2.61$ & $18.50 \pm 9.04$ & $18.50 \pm 9.04$ \\
\hline & & P8 & $25.45 \pm 2.63$ & $25.45 \pm 2.63$ & $15.50 \pm 7.50$ & $15.50 \pm 7.50$ \\
\hline
\end{tabular}




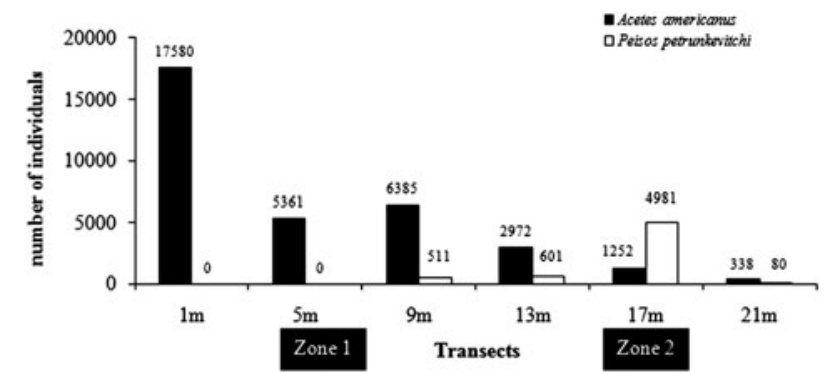

Fig. 4. Number of individuals of Acetes americanus and Peisos petrunkevitch sampled at depths of $1 \mathrm{~m}, 5 \mathrm{~m}, 9 \mathrm{~m}$ (Zone 1) and $13 \mathrm{~m}, 17 \mathrm{~m}$, and $21 \mathrm{~m}$ (Zone 2) in the Ubatuba bay, São Paulo.

loading is depth (-0.99), followed by bottom and surface salinity, which show similar signs as related to depth $(-0.56$ and -0.46 , respectively). However, given the high level of covariance among these variables, an inspection of their canonical weights can provide an indication of their individual contributions while controlling for other variables. Only depth shows high canonical weight $(\mathrm{CW}=-1.03)$, indicating that it most strongly reflects the variation in this environmental condition.

The variation among environmental factors was strongly associated with the abundance of $A$. americanus, as revealed by its high factor loading (0.87) and CW (0.93). Interestingly, the variation in abundance of $P$. petrunkevitchi was inversely related to factor loading $(-0.39)$ and $\mathrm{CW}(-0.50)$, as shown in Table 3 .

The highest number of $A$. americanus was found in locations with temperatures higher than $24^{\circ} \mathrm{C}$; however, no individuals were found in temperatures from $18^{\circ} \mathrm{C}$ to $20^{\circ} \mathrm{C}$ (Table 4). With regard to salinity, a higher number of individuals were found in sites with lower values of salinity from 28 to 30 (Table 5). The highest abundances of $P$. petrunkevitchi were found in locations with temperature ranges from 16 to $18^{\circ} \mathrm{C}$ and from 24 to $28^{\circ} \mathrm{C}$, and predominantly in sites with salinity values from 30 to 38 , with the greatest abundance in salinities from 34 to 36 , followed by 30 to 32 (Tables $4 \& 5$ ).

\section{DISCUSSIDN}

A distinct spatial distribution of both shrimp species was observed in the studied region. This result has also been observed in Penaeoidea shrimps. Primavera (1998) observed that three shrimp of the genus Metapenaeus (Wood-Mason,
Table 2. Acetes americanus and Peisos petrunkevitchi. Analysis of variance results for the mean catch by species, season and zone as well as their interactions.

\begin{tabular}{lllrrr}
\hline & Source & df & \multicolumn{1}{c}{ MS } & \multicolumn{1}{c}{ F } & P \\
\hline Acetes americanus & Seasons & 3 & 2.31 & 2.46 & 0.07 \\
& Zones & 1 & 25.77 & 27.51 & 0.00 \\
& Season $\times$ zones & 3 & 1.50 & 1.60 & 0.19 \\
Peisos petrunkevitchi & Seasons & 3 & 0.78 & 1.54 & 0.21 \\
& Zones & 1 & 3.20 & 6.36 & 0.01 \\
& Season $\times$ zones & 3 & 0.75 & 1.50 & 0.22 \\
\hline
\end{tabular}

df, degrees of freedom; MS, mean square; F, MS factor/MS residual; $P, 0.05$.

Table 3. Canonical factor loadings and associated weights based on the canonical correlation analysis of the relationship between environmental characteristics and shrimp abundance patterns.

\begin{tabular}{lcc}
\hline & Factor loadings & Canonical weights \\
\hline Depth & -0.99 & -1.03 \\
Surface temperature & 0.11 & 0.02 \\
Bottom temperature & 0.29 & -0.12 \\
Surface salinity & -0.46 & 0.08 \\
Bottom salinity & -0.56 & -0.08 \\
Acetes americanus & 0.87 & 0.93 \\
Peisos petrunkevitchi & -0.39 & -0.50 \\
\hline
\end{tabular}

1891) presented spatial partitioning based on different salinities and types of sediments. Macia (2004) and Costa et al. (2008) reported that juveniles of different Penaeidae species use different areas for nursery habitat to complete their life cycle. According to these authors, the spatial or temporal differentiation observed in closely related species can be due to avoidance of competition for food and territory. This hypothesis can be applied to both Sergestoidea species in this study.

Peisos petrunkevitchi is restricted to waters of $9 \mathrm{~m}$ or deeper with salinities close to 34 and usually where the temperature values drop. Boschi et al. (1981) also observed that on the Argentinean coast individuals were associated with salinities ranging from 33.2 to 33.9. These shrimps were not found near the shallow coastal waters, even during the periods in which the salinity was favourable to the establishment of this species. The combination of lower salinities and higher temperature values, observed in the shallow sites, may have limited the entrance of $P$. petrunkevitchi to the areas with depths of 1, 5 and $9 \mathrm{~m}$. The same pattern was observed by

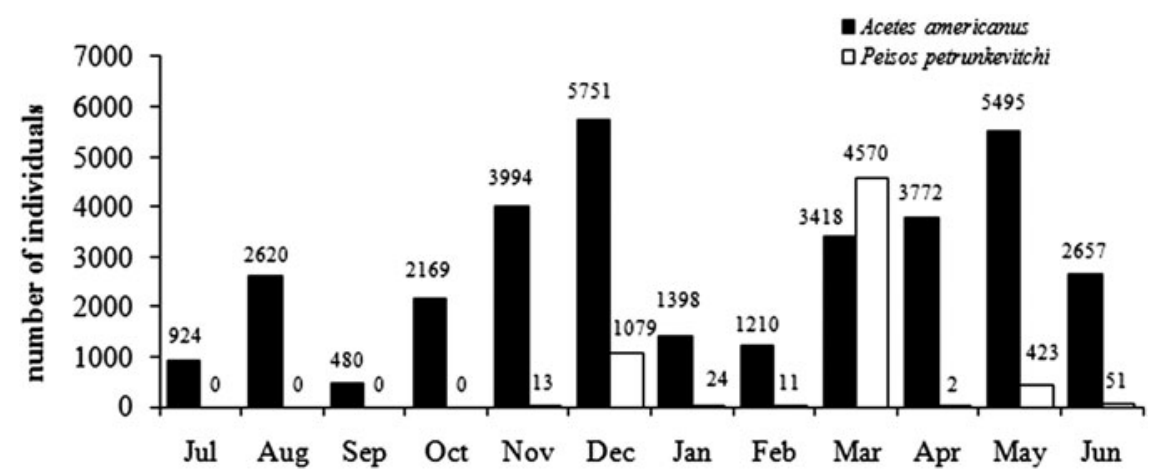

Fig. 5. Number of individuals of Acetes americanus and Peisos petrunkevitchi sampled by depth from July 2006 to June 2007 in the Ubatuba bay, São Paulo. 
Table 4. Number of individuals, number of trawls and number of individuals per trawl in relation to classes of temperature $\left({ }^{\circ} \mathrm{C}\right)$ observed for Acetes americanus and Peisos petrunkevitchi. The range of each class of temperature was $2^{\circ} \mathrm{C}$.

\begin{tabular}{lrrr}
\hline $\begin{array}{l}\text { Bottom } \\
\text { temperature }\left({ }^{\circ} \mathrm{C}\right)\end{array}$ & $\begin{array}{l}\text { Number of } \\
\text { trawls }\end{array}$ & $\begin{array}{l}\text { Number of } \\
\text { individuals }\end{array}$ & $\begin{array}{l}\text { Number of } \\
\text { individuals/trawl }\end{array}$ \\
\hline A. americanus & & & \\
$16-18$ & 26 & 3847 & 147.96 \\
$18-20$ & - & 0 & 0.00 \\
$20-22$ & 3 & 40 & 13.33 \\
$22-24$ & 51 & 5475 & 107.35 \\
$24-26$ & 39 & 13036 & 334.25 \\
$26-28$ & 22 & 7678 & 349.00 \\
$28-30$ & 11 & 3812 & 346.54 \\
$P$. petrunkevitchi & & & \\
$16-18$ & 10 & 1103 & 110.30 \\
$18-20$ & - & 0 & 0.00 \\
$20-22$ & 3 & 20 & 6.67 \\
$22-24$ & 11 & 487 & 44.27 \\
$24-26$ & 2 & 11 & 5.50 \\
$26-28$ & 5 & 4552 & 910.40 \\
$28-30$ & - & 0 & 0.00 \\
\hline
\end{tabular}

Table 5. Number of individuals, number of trawls and number of individuals per trawl in relation to classes of salinity observed for Acetes americanus and Peisos petrunkevitchi. The range of each class of salinity was 2 .

\begin{tabular}{lcrc}
\hline $\begin{array}{l}\text { Bottom } \\
\text { salinity }\end{array}$ & $\begin{array}{l}\text { Number of } \\
\text { trawls }\end{array}$ & $\begin{array}{l}\text { Number of } \\
\text { individuals }\end{array}$ & $\begin{array}{l}\text { Number of individuals/ } \\
\text { trawl }\end{array}$ \\
\hline A. americanus & - & 0 & 0.00 \\
$>22$ & 11 & 5515 & 501.36 \\
$22-24$ & - & 0 & 0.00 \\
$24-26$ & - & 0 & 0.00 \\
$26-28$ & 3 & 4313 & 1437.66 \\
$28-30$ & 15 & 4755 & 317.00 \\
$30-32$ & 7 & 1972 & 281.71 \\
$32-34$ & 79 & 13416 & 169.82 \\
$34-36$ & 37 & 3917 & 105.86 \\
$36-38$ & - & & \\
$P$. petrunkevitchi & 0 & 0.00 \\
$>28$ & 2 & 508 & 169.33 \\
$30-32$ & 23 & 2 & 243.48 \\
$32-34$ & 3 & 63 & 21.00 \\
$34-36$ & & & \\
$36-38$ & & 5600 & \\
\hline
\end{tabular}

Costa et al. (2004, 2005) for P. muelleri and Artemesia longinaris Bate, 1888 , respectively: both shrimps had geographical distributions similar to that of $P$. petrunkevitchi.

Additionally, $P$. petrunkevitchi possesses a distribution associated with colder temperate regions, primarily concentrated off the Argentinean coast in shallow areas, which generally do not surpass $20 \mathrm{~m}$ in depth and where water temperatures oscillate from 8 to $24^{\circ} \mathrm{C}$ (Mallo \& Boschi, 1982). The highest abundance of $P$. petrunkevitchi occurred in those months, which showed a decrease in the temperature and salinity values, due to the mass of SACW, possibly triggering the displacement of this species into the study area.

Therefore, $P$. petrunkevitchi can be considered to be a cold water shrimp similar to the other two species, A. longinaris and P. muelleri, which are typical of the South Atlantic
Ocean and were studied by Fransozo et al. (2004), Costa et al. $(2004,2005)$ and Castilho et al. $(2007,2008 \mathrm{~b})$ in the same region as this study.

Depth was also a determinant in the spatial distribution of the A. americanus shrimp, which showed a preference for shallow sites with high temperature and lower salinity values. In the field, it was observed that individuals were regularly captured in high quantities when they were aggregated among algae fragments, wood and leaf litter. Fransozo et al. (2009) found similar results for the Palaemonidae shrimp Nematopalaemon schimitti (Holthuis, 1950). This species was observed in high numbers only in sites with increased amounts of algae and algal fragments. In shallow coastal waters, where there is constant wave motion, those fragments may offer some protection to the shrimps. The trawl net was always observed containing these fragments, which was also the case for Omori (1974), who found the same to be true for Acetes shrimps, in which most specimens usually occurred associated with fragments and loose leaf litter near the substrate.

Acetes americanus prefers sites with higher temperature values. Xiao \& Greenwood (1993) observed that higher numbers of individuals were found in the warmer months of the year, both in tropical and subtropical regions. Calazans $(1994,2002)$ also observed a positive relationship between $A$. americanus larvae and temperature, i.e. a higher abundance of larvae was observed in warmer months in southern Brazil. Bhattacharya (1988) cited in Xiao \& Greenwood (1993), in a study conducted on Acetes indicus (H. Milne Edwards, 1830), found that this species prefers regions with temperatures ranging from 22 to $25^{\circ} \mathrm{C}$ and tolerates extremes of 14 and $34^{\circ} \mathrm{C}$. These results differed from ours, given that we observed a higher abundance of $A$. americanus in areas with temperatures from 23.5 to $28.5^{\circ} \mathrm{C}$. In contrast, in a study conducted by Chiou et al. (2000), the density and migration of Acetes intermedius Omori, 1975 from the estuary to shallower areas on the coast were related to heavy rains and a high discharge of water into the rivers.

Omori (1975) stated that the genus Acetes occurs in estuarine waters. According to the post-larvae total length (TL) of $2.50 \mathrm{~mm}$ (Calazans, 1994) and maturity at approximately $7.50 \mathrm{~mm}$ (Simões, 2008), it can be summarized that the individuals with TL greater than $3.00 \mathrm{~mm}$ are still considered juveniles. As in the present study, the smallest individuals captured for both species had a TL of $4.1 \mathrm{~mm}$, and no individual with this size was captured within the estuarine zones. Therefore, it is probable that most juveniles and adults of these species do not inhabit this environment. In contrast, we cannot confirm that these species do not have a life cycle linked to the estuarine area. Future studies should be undertaken using the appropriate nets to corroborate this hypothesis.

We note that in the summer, there was an increase in the number of individuals of $A$. americanus that matched an increase in primary production observed by Aidar et al. (1993) in Ubatuba. According to Castro-Filho et al. (1987), the SACW, in addition to transporting cold water, is a rich nutrient source. Once A. americanus shows a pelagic life habitat, the higher number of individuals would likely be related to the increased availability of food.

The assertions above are supported by the present results. Both species of Sergestoidea showed distinct distributions in time and space, and their establishment was related to the 
environmental factors analysed during the study. Future work involving population dynamics, reproductive traits, and vertical migratory patterns should be conducted to gain a better understanding of the biology of these species.

\section{ACKNDWLEDGEMENTS}

We are grateful to the Coordenação de Aperfeiçoamento de Pessoal de Nível Superior (CAPES) and Fundação de Amparo á Pesquisa do Estado de São Paulo (FAPESP) for providing financial support (\#09/54675-4, \#10/50188-8 and \#04/07309-8). We also thank the co-workers of NEBECC for their help during the fieldwork. All experiments conducted in this study complied with the current applicable state and federal laws in Brazil.

\section{REFERENCES}

Abessa D.M.S. and Burone L. (2003) Toxicidade de sedimentos dos rios situados na Enseada de Ubatuba (SP, Brasil). O Mundo da Saúde 27 $564-569$.

Aidar E., Gaeta S.A., Gianesella-Galvão S.M.F., Kutner M.B.B. and Teixeira C. (1993) Ecossistema costeiro tropical: nutrientes dissolvidos, fitoplâncton e clorofila-a, e suas relações com as condições oceanográficas na região de Ubatuba. Publicação especial do Instituto Oceanográfico 10, 9-43.

Boschi E.E., Iorio M.I. and Fischbach C. (1981) Distribución y abundance de los crustáceos decápodos capturados em lãs campañas de los B/I 'Walther Herwing' y 'Shinkai Marú' em El Mar Argentino, 1978 - 1979. Contribución Instituto Nacional Investigación Desarrollo Pesquero 383, 233-253.

Burone L. and Pires-Vanin A.M.S. (2006) Foraminiferal assemblages in Ubatuba Bay, south-eastern Brazilian coast. Scientia Marina 70 $203-217$

Calazans D. (1994) Morphology, abundance and distribution of larval phases of two sergestids in the southern Brazilian coast. Nauplius 2 , $75-86$.

Calazans D. (2002) Seasonal larval composition and abundance of shrimps in the surrounding area of the Patos Lagoon mouth Nauplius 10, 111-120.

Campos E.J.D., Gonçalves J.E. and Ikeda Y. (1995) Water mass charac teristics and geostrophic circulation in the South Brazil Bightsummer of 1991. Journal of Geophysical Research 100, 18537-18550.

Castilho A.L., Costa R.C., Fransozo A. and Boschi E.E. (2007) Reproductive pattern of the South American endemic shrimp Artemesia longinaris (Decapoda, Penaeidae), off São Paulo State, Brazil. Revista de Biología Tropical 55, 39-48.

Castilho A.L., Pie M.R., Fransozo A., Pinheiro A.P. and Costa R.C. (2008a) The relationship between environmental variation and species abundance in shrimp community (Crustacea: Decapoda: Penaeoidea) in south-eastern Brazil. Journal of the Marine Biological Association of the United Kingdom 88, 119-123.

Castilho A.L., Costa R.C., Fransozo A. and Negreiros-Fransozo M.L. (2008b) Reproduction and recruitment of the South American red shrimp, Pleoticus muelleri (Crustacea: Solenoceridae), from the southeastern coast of Brazil. Marine Biology Research 4, 361-368.

Castro-Filho B.M., Miranda L.B. and Myao S.Y. (1987) Condições hidrográficas na plataforma continental ao largo de Ubatuba: variações sazonais e em média escala. Boletim do Instituto Oceanográfico 35 , $135-151$.
Castro-Filho B.M. and Miranda L.B. (1998) Physical oceanography of the western Atlantic continental shelf located between $4{ }^{\circ} \mathrm{N}$ and $34^{\circ} \mathrm{S}$ coastal segment $\left(4^{\circ} \mathrm{W}\right)$. The Sea 11, 209-251.

CETESB (Companhia de Tecnologia de Saneamento Ambiental) (1996) Relatório de Balneabilidade das Praias Paulistas-1995. São Paulo: Secretaria do Meio Ambiente.

CETESB (Companhia de Tecnologia de Saneamento Ambiental) (2000) Relatório de Balneabilidade das Praias Paulistas-1999. São Paulo: Secretaria do Meio Ambiente.

Chiou W.D., Wu C.C. and Cheng L.Z. (2000) Spatio-temporal distribution of sergestid shrimp Acetes intermedius in the coastal waters of southwestern Taiwan. Fisheries Science 66, 1014-1025.

Costa R.C., Fransozo A., Mantelatto F.L.M. and Castro R.H. (2000) Occurrence of shrimp species (Crustacea: Decapoda: Natantia: Penaeidea and Caridea) in Ubatuba Bay, Ubatuba, SP, Brazil. Proceedings of the Biological Society of Washington 113, 776-781.

Costa R.C., Fransozo A., Melo G.A.S. and Freire F.A.M. (2003) An illustrated key for Dendrobranchiata shrimps from the northern coast of São Paulo state, Brazil. Biota Neotropica 3, 1-12. Available at: $<$ http://www.biotaneotropica.org.br/v3n1 (accessed 30 April 2012).

Costa R.C., Fransozo A. and Pinheiro A.P. (2004) Ecological distribution of the shrimp Pleoticus muelleri (Bate, 1988) (Decapoda: Penaeoidea) in southeastern Brazil. Hydrobiology 529, 195-203.

Costa R.C., Fransozo A., Castilho A.L. and Freire F.A.M. (2005) Annual, seasonal and spatial variation of abundance of the shrimp Artemesia longinaris (Decapoda: Penaeoidea) in south-eastern Brazil. Journal of the Marine Biological Association of the United Kingdom $85,107-112$

Costa R.C., Lopes M., Castilho A.L., Fransozo A. and Simões S.M. (2008) Abundance and distribution of juvenile pink shrimps Farfantepenaeus spp. in a mangrove estuary and adjacent bay on the northern shore of São Paulo State, southeastern Brazil. Invertebrate Reproduction and Development 52, 51-58.

D'Incao F. and Martins S.T.S. (2000) Brazilian species of the genus Acetes H. Milne Edwards, 1830 and Peisos Burkenroad, 1945 (Decapoda: Sergestidae). Journal of Crustacean Biology 20, 78-86.

Dall W., Hill B.J., Rothilsberg P.C. and Staples D.J. (1990) The biology of the Penaeidae. Advances in marine biology. San Diego, CA: Academic Press, 489 pp.

Fransozo A., Costa R.C., Castilho A.L. and Mantelatto F.L.M. (2004) Ecological distribution of the shrimp 'camarão-serrinha' Artemesia longinaris (Decapoda: Penaeidae) in Fortaleza Bay, Ubatuba, Brazil, in relation to abiotic factors. Revista de Investigación y Desarrollo Pesquero 16, 43-50.

Fransozo V., Castilho A.L., Freire F.A.M., Furlan M., Almeida A.C., Teixeira G.M. and Baeza J.A. (2009) Spatial and temporal distribution of the shrimp Nematopalaemon schmitti (Decapoda: Caridea: Palaemonidae) at a subtropical enclosed bay in South America. Journal of the Marine Biological Association of the United Kingdom $89,1581-1587$.

Macia A. (2004) Juvenile penaeid shrimp density, spatial distribution and size composition in four adjacent habitats within a mangrove-fringed bay on Inhaca Island, Mozambique. Western Indian Ocean Journal of Marine Science 3, 163-178.

Mallo J.C. and Boschi E.E. (1982) Contribución al conocimiento del ciclo vital del camarón Peisos petrunkevitchi de la región de Mar del Plata Argentina (Crustacea, Decapoda, Sergestidae). Physis 41, 85-98.

Nogueira Júnior M. and Haddad M.A. (2008) The diet of cubomedusae (Cnidaria, Cubozoa) in southern Brazil. Brazilian Journal of Oceanography 56, 157-164. 
Omori M. (1974) The biology of pelagic shrimps in the ocean. Advances in Marine Biology 12, 233-324.

Omori M. (1975) The systematics, biogeography, and fishery of epipelagic shrimps of the genus Acetes (Crustacea, Decapoda, Sergestidae). Bulletin of the Ocean Research Institute, University of Tokyo 7, 1-91.

Oshiro L.M.Y. and Omori M. (1996) Larval development of Acetes americanus (Decapoda: Sergestidae) at Paranaguá and Laranjeiras bays, Brazil. Journal of Crustacean Biology 16, 709-729.

Primavera J.H. (1998) Mangroves as nurseries: shrimp populations in mangrove and non-mangrove habitats. Estuarine, Coastal and Shelf Science 46, 457-464.

Roux A., Piñero R., Moriondo P. and Fernández M. (2009) Diet of the red shrimp Pleoticus muelleri (Bate, 1888) in Patagonian fishing grounds, Argentina. Revista de Biología Marina y Oceanografía 44, $775-781$.

Simões S.M. (2008) Distribuição e Dinâmica Populacional dos camarões sergestídeos, Acetes americanus americanus Ortmann, 1893 e Peisos petrunkevitchi Burkenroad, 1945 (Dendrobranchiata, Sergestidae), na região de Ubatuba, Litoral Norte do Estado de São Paulo. Dissertação de mestrado. Universidade Estadual Paulista, Botucatu, Brasil.

Simões S.M., Costa R.C., Fransozo A. and Castilho A.L. (2010) Diel variation in abundance and size of the seabob shrimp Xiphopenaeus kroyeri (Crustacea, Penaeoidea) in the Ubatuba region, southeastern Brazil. Anais da Academia Brasileira de Ciências 82, 369-378.

Valentin J.L. and Monteiro-Ribas W.M. (1993) Zooplankton community structure on the east-southeast Brazilian continental shelf (18$23^{\circ} \mathrm{S}$ latitude). Continental Shelf Research 13, 407-424.

Williams A.B. (1965) Marine decapod crustaceans of the Carolinas. Fishery Bulletin of the U.S. Fish and Wildlife Service 65, 1-298.

Xiao Y. and Greenwood J.G. (1993) The biology of Acetes (Crustacea, Sergestidae). Oceanography and Marine Biology: an Annual Review $31,259-444$.

and

Zar J.H. (1999) Biostatistical analysis. 4th edition. Upper Saddle River, NJ: Prentice-Hall, 662 pp.

\section{Correspondence should be addressed to:}

R.C. Costa

LABCAM (Laboratório de Biologia de Camarões Marinhos e de Água Doce),

Departamento de Ciências Biológicas, Faculdade de Ciências UNESP, 17033-360, Bauru, SP, Brasil

email: rccosta@fc.unesp.br 